\title{
MULTICRITERIA EVALUATION OF COMMERCIAL INDUSTRIAL ZONE DEVELOPMENT
}

\author{
Andželika KOMAROVSKA a, Leonas USTINOVICHIUS a, Galina SHEVCHENKO ${ }^{\text {b,*, }}$ \\ Lukasz NAZARKO ${ }^{\mathrm{C}}$ \\ a Department of Construction Technology and Management, Faculty of Civil Engineering, Vilnius \\ Gediminas Technical University, Sauletekio al. 11, LT-10223 Vilnius, Lithuania \\ ${ }^{b}$ Department of Economics and Management of Enterprises, Faculty of Business Management, Vilnius \\ Gediminas Technical University, Sauletekio al. 11, LT, 10223 Vilnius, Lithuania \\ ${ }^{c}$ Department of Economics and Social Sciences, Faculty of Management, Bialystok University of \\ Technology, Wiejska ave. 45A, 15-351 Biatystok, Poland
}

Received 22 May 2013; accepted 20 February 2015

\begin{abstract}
The article presents the results of the analysis of Vilnius district commercial-industrial zones. The criteria of analysis are: geographic location, plots and/or groups of plots in the area, operating and planning activities of companies as well as the infrastructure and transport communications development at the engineering level. A theoretical model for investment strategy selection is introduced to identify the possibilities of investment attractiveness. The principle of the investment option with the system of characterizing indicators for development is offered to reflect the lack of cohesion between practical investment promotion and sustainable development of the territories' indicators.
\end{abstract}

KEYWORDS: Investment attractiveness; Commercial industrial zone (CIZ); Free economy zones (FEZ) investment incentives; Multicriteria decision-making; Compromise solution; Spatial planning

\section{INTRODUCTION}

The investment attractiveness of a region is perceived as the investment opportunities that could be economically beneficial to an investor by choosing an investment object in a particular region (Brown 2012; Meng 2012). Each region has individual characteristics describing its potential attractiveness to investors; therefore, it is important to set the strategic development directions. It is necessary to carry out series of studies and analyses in order to evaluate the investment possibilities of a region (Cha, Kim 2011). A high level of competitiveness and investment attractiveness of a region boosts formation of new businesses, creates additional jobs, ensures the use of local resources for investment in the region, guarantees economic and investment income, but also promotes effective social and economic planning and development of the infrastructure. The formation of an attractive investment climate should be a priority while solv-

\footnotetext{
* Corresponding author. E-mail: galina.sevcenko@vgtu.lt
}

ing regional problems in Lithuania. The country's economic situation depends on it more than on any other factor (Nausèda, Tamošiūnas 2009).

Spatial/territorial planning is one of the measures for implementation of sustainable development and assurance of investments in the region. Studies regarding the territorial planning processes in Germany and Poland focus on their legal frameworks, goals, objectives and the content of the prepared plans. The results of that research allowed distinguishing essential elements that could be adapted to modernize the territorial planning process in Lithuania (Ustinovichius et al. 2011). Sustainable development comprises purposeful national and/or regional infrastructure development embracing spatial planning, competitiveness, an array of investment incentives, implementation of new construction projects, promotion of the rational building use, improvement of the energy recovery processes etc. (Mori, Christodoulou 2012; Dahl 2012; Niccolucci et al. 2012). All of these is- 
sues may not be properly addressed without the consideration of the technical, economic, social, environmental and other risks inherent in all of the processes mentioned above.

Political and regulatory risks on pending processes in the assessment of investment attractiveness of a region have not been defined in the literature. There is a lack of assessment practice, criteria and methods. Even if such research is carried out it is done in the regions but not at the national level.

The impact of competition is positive if investment incentives allow local businesses a more productive use of existing resources, or take over the newly brought-in high technology (Ruane 2008). Otherwise, competitiveness of local companies reduces and they get slowly pushed out of the market. The investment intensification policy and measures chosen by state institutions make it possible to integrate the region's capital market, to expand production using local labour, land and funds. However, in anticipation of a positive impact of the funds, the economic situation in a country or region and the need for investment in a given district are not always assessed. Usually, the most common primary goal of state institutions is to provide as much funding as possible for regions (Singh 2005; Falla et al. 2009). The investments are necessary not only for financial and technological corporate restructuring or for the introduction of new technologies, but also for the strategic and successful development of the infrastructure of an entire district (Ginevičius, Šimelytè 2012; Rutkauskas et al. 2008; Ruplienè, Garšvienè 2008; Lim 2008).

Ensuring the investment attractiveness, competitiveness and innovation are the key issues of strategic development under the market economy conditions. This proves the relevance of this paper as the investment risk has a great influence on the level of investment attractiveness of territories (infrastructure) in a region. Targeted investment risk assessment and management are taken as the basis for targeted management decisions.

Social and economic regional growth is possible only with increasing investments (Nauseda, Tamošiūnas 2009). Investment attractiveness (shaping the investment climate) is a very serious task aimed at attracting and focusing the use of local and foreign investment funds. State authorities are required to acquire comprehensive management skills to attract investments and to use them purposefully. In order to study alternative solutions and select the most favourable one, it is advisable to rely on the experience of highly developed countries, evaluate future positive or negative trends regarding the effects of the funding expansion, and use the latest methods for the assessment of sustainable development and of multi-criteria evaluation (Keršytè 2010; Sakalauskas, Zavadskas 2009; Ginevičius, Podvezko 2009; Ginevičius, Bruzgè 2008). Therefore, in order to purposefully direct investment flows into the branches of a business problem (or problem areas), it is necessary to have a targeted investment implementation plan (Keršytė 2010; Sakalauskas, Zavadskas 2009; Ginevičius, Podvezko 2009; Ginevičius, Bruzgè 2008). This is the reason why it is necessary to develop an investment strategy for regional development (or an implementation model) that would allow forming investment directions. This is especially important for the District of Vilnius, which has a high concentration of social, economic, technological, environmental and other aspects that can affect the development of the entire country.

The article explores the problems of investment intensification, targeted measures to attract investments, and the ability of the District of Vilnius to adapt in order to retain the long-term positive impact on the district and state development.

\section{INTERFACE BETWEEN INVESTMENTS AND SPATIAL/TERRITORIAL PLANNING}

A spatial/territorial planning system is regarded as a complex multi-dimensional process, during which the decision-making considers natural, economic, demographic, planning, engineering, managerial and other factors. The effect of these factors is methodologically evaluated in terms of three main aspects: economic, social and environmental. Cohesion of those aspects ensures harmonious development of a territory. Sustainable development assumptions must be validated by spatial/territorial planning legislation.

Current regulatory framework for spatial planning in Lithuania encourages private investments into effectively and profitably used plots, but does not create a framework for sustainable development. EU legislation does not regulate spatial/ territorial planning, leaving this right to member states. The main tool of this process is the national spatial/territorial planning legislation. Investors are faced with lower or higher risks in each phase of project implementation. Unfair and disproportionate distribution of risk may result in price increase, extended project duration, legal disputes 
and, ultimately, the failure of the investment project. Researchers analyse investment, construction project and risk identification models associated with their implementation, methods, recommendations, risk distribution and reduction methods (Zavadskas et al. 2014; Ustinovichius et al. 2011). There is, however, no evaluation of risks particular to design of spatial planning documents that are rather unpredictable and can have a decisive impact on an investment project. Therefore, it is important to undertake a systematic analysis of the spatial planning process and provide a suitable decision making method.

The National Strategy for Sustainable Development, approved by the Seimas (Parliament) of the Republic of Lithuania shows validation of the sustainable development concept. However, the Law on Spatial Planning does not provide a definition for sustainable development and there are no criteria and methodology of such planning approved. As the research shows, the state and municipalities do not actually have enough resources to carry out relevant policies despite the declared sustainable development. Although private and social investments have increased, municipalities fail to support new residential areas with necessary infrastructure. In the Municipality of Vilnius, engineering, transport and social infrastructure development takes place only with the consent of investors (individual or legal person) in good faith.

There is a wide variety of problems in the sector of spatial planning. Global energy, climate change, demographic and cultural factors, social engineering infrastructure and the lack of communications pose a serious challenge to our cities, towns, villages and their inhabitants. Developed plans should ensure sustainable spatial development, economic growth, job creation, attraction of investments, public infrastructure development. Therefore, it is necessary to develop an integrated system for the national plan implementation. This requires to define the criteria and the system that can provide comprehensive and objective spatial development and change analysis, information collection, processing and storage, as well as decisionmaking and the preparation structure (Jakaitis et al. 2009; Mori, Christodoulou 2012; Dahl 2012).

Development perspectives and restrictions as well as construction regulations are determined in the spatial planning documents, depending on their level, goals and objectives. Spatial planning document solutions are implemented during the construction process, therefor these two processes should not be separated. Investments are required for implementation of solutions provided in spatial planning documents. It is important for these investments to be valid and help meet social needs of the public as well as develop public infrastructure, and contribute to the well-being of future generations. According to Galinienè and Mašalaitytè (2007), there is no business that has no efficiency issues. Resources, production process, service performance, employee activities and management efficiency are in no way isolated or separated from one another. One should consider adding the list of efficiencies to the spatial planning process, documented solutions and to the legislation efficiency aspects.

In order to attract investments and use them purposefully, public authorities are required to develop competences to skilfully manage economy of a country or a district (Ruplienè et al. 2008). Assessing possible positive or negative effects of expanded funding, it is best to rely on experience of economically developed countries. The latest models should be considered for searching and to selection of alternative solutions in the context of sustainable development (Skibniewski, Zavadskas 2013; Ghosh et al. 2012; Marques et al. 2011; Negahban et al. 2012; Zolfani et al. 2012; Zavadskas et al. 2014). In order to identify the investment opportunities and purposefully direct investment flows into the targeted businesses and/or districts, it is necessary to create a focused investment strategy and/or a model and to minimize the potential risk factors (Fig. 1) (Fouladgar et al. 2012). In order to achieve this objective, a complex analysis of a region is suggested. The complex analysis consists of three major blocs: macroeconomic analysis, analysis of the investment climate and analysis of the investment strategy. These analyses are recommended because:

1. The macroeconomic analysis of the region sets the ways to improve the existing investment environment and helps to create an effective domestic and foreign direct investment promotion system.

2. The investment climate analysis assesses the potential of the region, spatial planning documents and business development opportunities.

The analysis of possible strategic development directions and the SWOT analysis establish strengths, weaknesses, opportunities and threats for the region that may impact on the region's business and investment environment. In addition, it determines possible strategic development directions $\left(K_{1}, K_{2}, K_{3} \ldots K_{n}\right)$. 


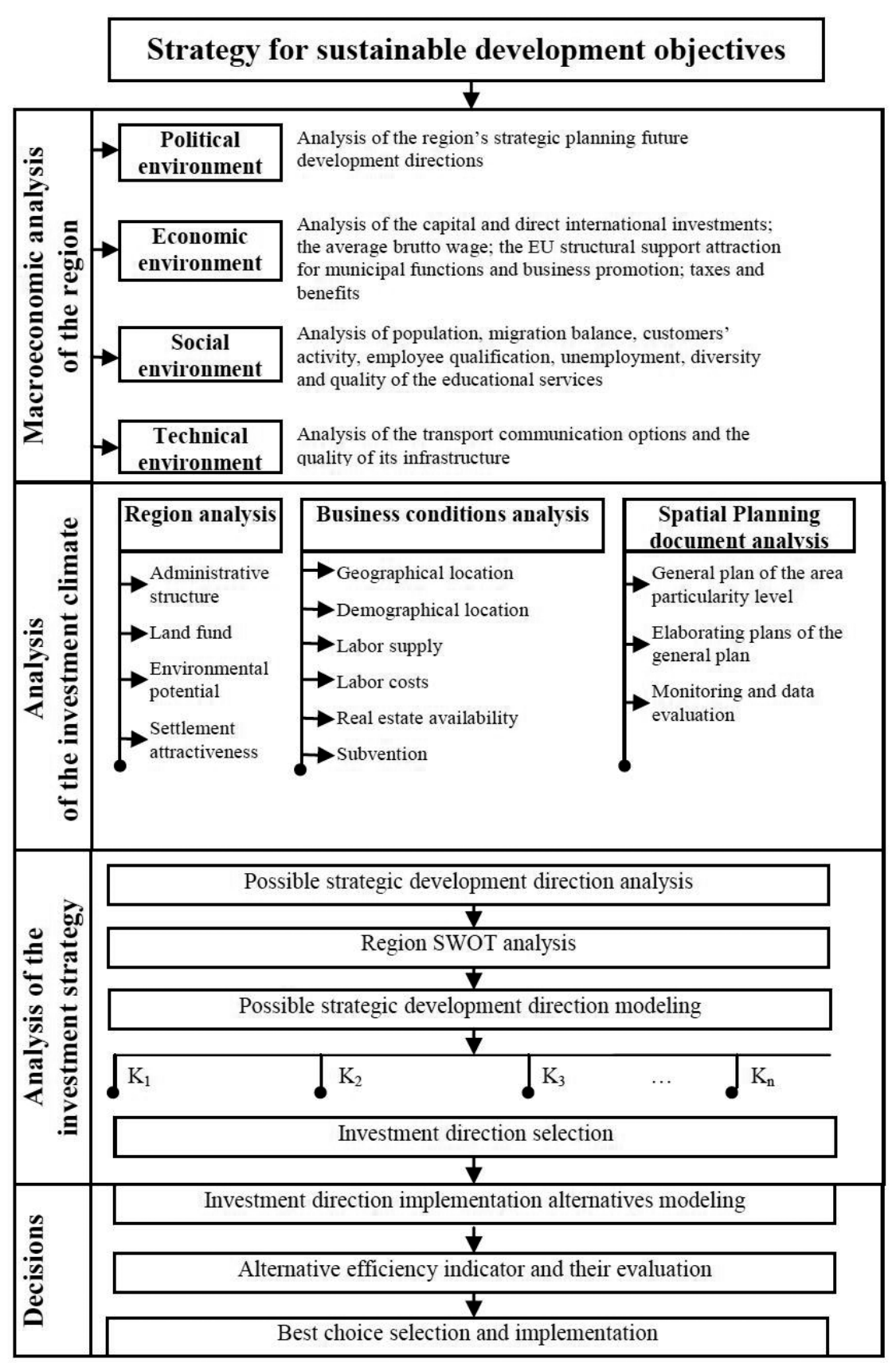

Fig. 1. Model for determination of an investment strategy

The potential of a region may be assessed by the following indicators:

- administrative structure (prevailing places of residence, location, size and number);

- land ownership (state, municipality, privately owned land balance, completeness of the land reform);

- tourism potential (portion of surface waters in the region and their quality; forests and protected areas such as parks, reserves etc.; elements of cultural heritage and their condition and dependence; tourist routes - pedestrian, biking paths etc.; recreational and entertainment facilities);
- attractiveness of the place (centralized utility services such as water supply and wastewater management); quality centralized water supply, quality of communications; social infrastructure; development of public spaces, environmental quality);

- clusters (CIZ, FEZ, business incubator etc.).

Regional business conditions may be assessed by the following indicators:

- geographical location (regional positioning, nearby objects);

- demographical location (population, potential of working age people);

- labour supply; 
- labour costs;

- real estate availability;

- subventions.

The importance of geographical location in the context of attracting investments and improving business conditions derives from the following facts:

- geographical location determines the arrival availability, transportation costs and duration;

- nearby large cities or other strategic objects affect migration of population in the district and business formation potential.

It is very important to express strategic goals in the regional/district spatial planning documents. It is crucial to observe the consistency of set goals and their compatibility with the plans. When selecting/ setting the strategic development direction for a region, it is strongly suggested to prepare a detailed examination of spatial planning documents and monitoring results (Ustinovichius et al. 2011).

Centres attractive for investment, business, entertainment and population must be set while analysing a regional administrative structure. The absence of such a centre results in the lack of population concentration, loss of a certain businesses potential and reduction in attractiveness for investments.

Land ownership analysis shows the distribution of land according to the main purpose of land use and ownership. Assessing the condition of soil of the predominant land in the region affects the choice of business nature. The land ownership rights in the region impact on the government options to implement the strategic goals (with regard to the opinion/influence of/by land owners and the Ministry of Agriculture of the Republic of Lithuania).

CHARACTERISTICS

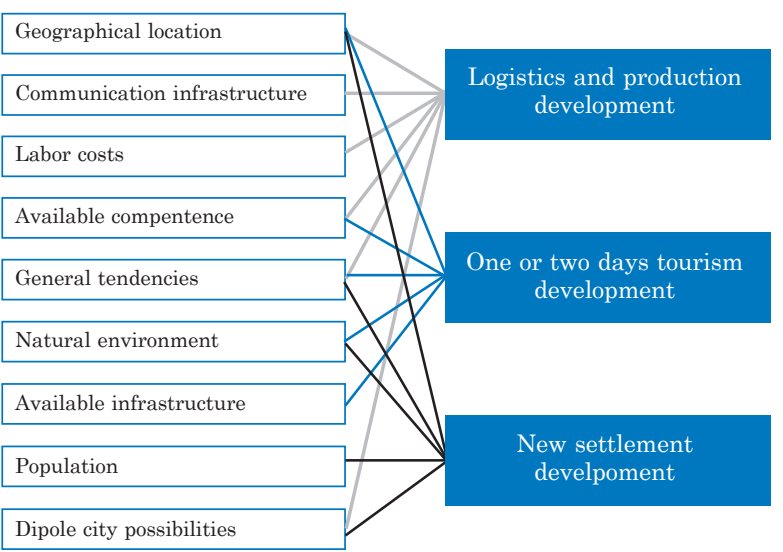

Fig. 2. Main development strategies and the factors influencing them

\section{STRATEGY STAGE SPECIFICATION}

The District of Vilnius, like any other territorial unit (or entity), cannot be competitive in all sectors of economy as both the resources and opportunities are limited. In order to achieve the economic growth, it is important to identify priority areas because only expedient planning rather than the orientation of many areas makes it possible to achieve clear goals and particular results.

The analysis of the macroeconomic situation and investment climate of the District of Vilnius resulted in the identification of three possible strategic directions for promotion of investments: logistics and production; one or two day tourism; new settlement development (Fig. 2). The diagram shows the main characteristics of the District of Vilnius that influence the identified strategic directions.

According to the real estate market studies conducted in the District of of Vilnius, there is a very high demand for industrial areas, but none are set. It was also identified that the most attractive industrial territory development areas are at $30 \mathrm{~km}$ distance from Vilnius and have a good access to the city.

The selection of the strategic development direction for production and logistics in the District of Vilnius was mainly based on the following aspects:

- advantageous geographical location. The proximity of two biggest cities of Lithuania - Vilnius and Kaunas, and international airports of Vilnius and Kaunas, as well as foreign countries - Poland and Belarus, make the District of Vilnius accessible locally and internationally;

- advanced communications infrastructure. The main transit cargo/passenger highways that connect Klaipeda seaport (the main cargo and logistics centre) with Vilnius, Belarus, Ukraine and Russia as well as other major Lithuanian highways pass through the District of Vilnius. Developed communications infrastructure makes the District of Vilnius particularly attractive to companies engaged in the manufacturing, export or import, logistics and warehousing services;

- competitive labour costs. The District of Vilnius has competitive labour costs compared to average national labour costs, costs in other districts located near major cities of Lithuania and those of Polish provinces located close to the Lithuanian border;

- available competence. The District of Vilnius has a large base of companies engaged 
in logistics and manufacturing. Currently, a public logistics centre is under construction in the municipality of Pagiriai. It is expected for the production to develop in the area, so it would be appropriate to continue the development of the existing competences;

- general tendencies. Western countries already have a tendency to set up logistics centres and production facilities in the nearby and strategically convenient areas away from major cities rather than inside them. Such logistics centres are expanding especially rapidly in Poland, where most of them are located near the capital city and allow the country to maintain its status of a transit country.

\section{DESCRIPTION OF \\ COMMERCIAL-INDUSTRIAL ZONES IN THE DISTRICT OF VILNIUS}

Development of free economic zones (FEZ), industrial parks (IP) and commercial-industrial zones (CIZ) is highly important for investment opportunities in the region. A region may expect the high- est economic and social effectiveness having developed areas that are adjusted to investor needs that can be used with minimum risk and on attractive terms.

The feasibility study on the development of an industrial park (Paliokaite et al. 2007) shows that there is a low supply of IP while its demand in the District of Vilnius is high. The study also states that the most attractive areas for new IP development are located at a $30 \mathrm{~km}$ distance from the city of Vilnius and with good access to the city. As the District of Vilnius meets both mentioned criteria, IP creation in the District of Vilnius is a purposeful step. The District of Vilnius has a number of commercial areas; however, there are no IP, FEZ or zones with the required infrastructure and conducive economic and legal conditions for commercial activities. It should be noted that most industrialcommercial zones are located in areas that are close to boundaries of Vilnius City Municipality and the main roads. There is a number of companies with 50 hectare territory in more distant settlements, and there is no sign of new industrial companies settling or planning to settle close to

Table 1. Main characteristics of isolated industrial-commercial zones

\begin{tabular}{|c|c|c|c|c|c|c|}
\hline No. & CIZ name & Size (ha) & $\begin{array}{l}\text { Level of engi- } \\
\text { neering and } \\
\text { communication } \\
\text { infrastructure } \\
\text { development }\end{array}$ & $\begin{array}{l}\text { Number of } \\
\text { companies }\end{array}$ & Operating activities & $\begin{array}{l}\text { CIZ deve- } \\
\text { lopment } \\
\text { opportu- } \\
\text { nities }\end{array}$ \\
\hline 1. & Bendoriai-Bukiškis & about 65 & High & 15 & $\begin{array}{l}\text { Logistics, transportation } \\
\text { companies, mostly com- } \\
\text { mercial trade, services and } \\
\text { entertainment facilities }\end{array}$ & High \\
\hline 2. & Budninkai-Glatkiškès & 37,9 & Average & 7 & $\begin{array}{l}\text { Various activities; mainly } \\
\text { factories, storage facilities }\end{array}$ & Average \\
\hline 3. & Didžiasalis-Skaidiškis & 21,6 & Good & 5 & $\begin{array}{l}\text { Various activities; mainly } \\
\text { storage facilities, logistics } \\
\text { centres presumed }\end{array}$ & Average \\
\hline 4. & Didžioji Riešè-Gulbinai & about 50 & High & 12 & $\begin{array}{l}\text { Number of factories, set or } \\
\text { to be set storages, malls, } \\
\text { commercial facilities, logis- } \\
\text { tics centres }\end{array}$ & High \\
\hline 5. & Kuprioniškès & 18,5 & High & 7 & $\begin{array}{l}\text { Centres providing mainly } \\
\text { logistics and warehousing } \\
\text { services }\end{array}$ & High \\
\hline 6. & $\begin{array}{l}\text { Maišiagala-Avižieniai- } \\
\text { Sudervė }\end{array}$ & 295 & High & 10 & $\begin{array}{l}\text { Various activities; the larg- } \\
\text { est area belongs to Villon } \\
\text { hotel and entertainment } \\
\text { and sports complexes }\end{array}$ & High \\
\hline 7. & Maišiagala & 30,8 & High & 7 & Various activities & Average \\
\hline 8. & Nemėžis & 7,76 & Good & 4 & Various activities & Low \\
\hline 9. & Pagiriai & 85,1 & High & 3 & $\begin{array}{l}\text { Mainly JC "Pagirių } \\
\text { šiltnamiai" }\end{array}$ & Average \\
\hline 10. & Riešè (western part) & 52,1 & Average & 8 & $\begin{array}{l}\text { Various activities; operat- } \\
\text { ing and planned industrial } \\
\text { objects }\end{array}$ & Average \\
\hline 11. & Rudamina & 160 & High & 3 & $\begin{array}{l}\text { Mainly JSC "Vilniaus } \\
\text { paukštynas" }\end{array}$ & High \\
\hline
\end{tabular}


these companies. In effect, there are no preconditions for those areas to be formed into industrialcommercial zones.

As a result of the environmental and commercial analysis conducted on the Vilnius District Municipality, 11 industrial-commercial zones were identified for already settled or new commercial, manufacturing, storage or other industry-related objects. These zones are concentrated in the north-western and southern parts of the District of Vilnius.

Table 1 shows the identified industrial-commercial zones with the indication of size, the level of engineering and communication infrastructure development, number of operating activities and development opportunities. It also determines the prospective development areas that have welldeveloped engineering and communication infrastructure and good development opportunities.

Identified areas differ not only in size but also in engineering infrastructure development levels, systems of communications, activities, opportunities and prospects for further development etc.

In order to determine what industrial-commercial zones are the most valuable to develop, the current situation of these zones was assessed by 4 groups of efficiency indexes measured on a scale. The industrial and commercial zones that are the most promising for development were determined by relative values of the estimates. In some medium-sized areas, a relatively small number of companies is located; however, a very welldeveloped engineering and communication infrastructure suggests possible further development of such areas. At the same time, large CIZ with a well-developed infrastructure but a small number of companies (mainly one big company) displays average development prospects.

After a review of the current state and perspectives of industrial-commercial zones in the District of Vilnius, three CIZ development alternatives were proposed:

A1 alternative - "minimal investments". In this case, industrial and commercial areas develop erratically in parallel with the development of the entire area, and all the established zones develop in the same level, with a proportional investment.

A2 alternative - "maximal investments". In this case, CIZ development is assigned to the most important development priorities of the District of Vilnius and the prioritized CIZ, i.e. maximum amount of the required investments is assigned for the development of the public logistics centre in a relatively short period of time.
A3 alternative - "efficient investments". In this case, the highest level of investments is focused on the development of the industrial-commercial zones that obtain the highest total score. The lowest score areas get the investments necessary only for their activity support. Public relations and marketing instruments are also used to attract more investors to the area.

\section{MULTICRITERIA ASSESMENT OF COMMERCIAL-INDUSTRIAL ZONES}

At first, the subjective and objective weights of attributes were determined. The subjective and objective analysis has a lot of advantages and disadvantages. Weights set in the subjective approach specify personal subjective solutions with the alternative ranking of the problem result. That takes much loosened values afterwards. Weights of the objective solutions are determined using mathematical methods based on subjective information.

None of the decision making methods is perfect. One needs to determine the most suitable method that will be the most appropriate for a particular purpose, in this case, for determining the criteria of weight calculation. A software model that integrates subjective (Saaty 1977) and objective (Hwang, Yoon 1981; Ustinovichius 2004) solutions was developed in order to determine the weights of the attributes. Three most popular quantitative methods described below were used in the study in order to obtain the most precise results.

Several articles aimed to combine the subjective and targeted information while solving MADM problems (Cook, Kress 1994; Liang, Wang 1994; Triantaphyllou 2000; Ustinovičius, Zavadskas 2004; Zavadskas, Turskis 2011). However, the models in question are rather difficult to work with (Yazdani-Chamzini et al. 2013a). The authors state that the connection of subjective and objective information is not a well-studied field and still requires a lot of further research.

Integrated, subjective and objective weights of attributes. The objective weights of attributes are better determined using the entropy method. Assume that $S=\left\{S_{1}, \mathrm{~S}_{2}, \ldots, S_{m}\right\}$ is discrete set of alternatives, $R=\left\{R_{1}, R_{2}, \ldots, R_{n}\right\}$ - a set of attributes and $X=\left[x_{i j}\right]_{m} \times_{n}$ - an alternative by attribute matrix, where $x_{i j}$ - is $R_{j}$ attribute value of alternative $S_{i}(i=1,2, \ldots, m . ; j=1,2, \ldots, n)$. In order to have the same scale of measurements, it is assumed that all the initial values of the matrix range from 0 to 1 . 
The value of the objective weights of the attribute is determined by the attribute dominance level. The subjective weight values show the relevance of the attribute to the alternatives considered. In some cases, $\overline{q_{j}}$ (subjective weight) and $q_{j}$ (objective weight) are essentially different, thereby considerably decreasing the accuracy of preference ordering of the alternatives. This may be accounted for the fact that minor factors can have a great influence on ranking the alternatives, and vice versa. Therefore, the formula for determining the objective weight of the attribute by the entropy approach can be interpreted as follows:

$$
\overline{q_{j}}=\frac{q_{j}^{*} q_{j}}{\sum_{j=1}^{n} q_{j}^{*} q_{j}}, \quad j=\overline{1, n} .
$$

To obtain the integrated weight of the attribute $q_{j}^{*}$, a system of equations given below should be solved using:

$$
\begin{aligned}
& \left(q_{1}^{*}\left(\overline{q_{1}} q_{1}-q_{1}\right)+q_{2}^{*} \overline{q_{1}} q_{2}+q_{3}^{*} \overline{q_{1}} q_{3}+\ldots+q_{n}^{*} \overline{q_{1}} q_{n}+f=0\right. \\
& q_{1}^{*} \overline{q_{2}} q_{2}+q_{2}^{*}\left(\overline{q_{2}} q_{2}-q_{2}\right)+q_{3}^{*} \overline{q_{2}} q_{3}+\ldots+q_{n}^{*} \overline{q_{2}} q_{n}+f=0 \\
& q_{1}^{*} \overline{q_{3}} q_{1}+q_{2}^{*} \overline{q_{3}} q_{2}+q_{3}^{*}\left(\overline{q_{3}} q_{3}-q_{3}\right)+\ldots+q_{n}^{*} \overline{q_{3}} q_{n}+f=0 \\
& \begin{array}{c}
\cdots \\
q_{1}^{*} \overline{q_{n}} q_{1}+q_{2}^{*} \overline{q_{n}} q_{2}+q_{3}^{*} \overline{q_{n}} q_{3}+\ldots+q_{n}^{*}\left(\overline{q_{n}} q_{n}-q_{n}\right)+f=0
\end{array} \\
& q_{1}^{*}+q_{2}^{*}+q_{3}^{*}+\ldots+q_{n}^{*}=1
\end{aligned}
$$

where: $f$ is error coefficient.

Later on, the weights $q_{j}^{*}$ will be used in multiattribute decision methods such as TOPSIS, SAW, COPRAS etc.

The initial data of the regional investments are summarized in Table 2. Technical, economic, environmental, social marking of groups of attributes presented at the end of the Table 2 were used in the evaluation of attributes. Subjective attributes and their weights were determined through an expert-based analysis. The engaged experts were the leading specialists in the field of construction investments. The level consistency in expert opinions was considered sufficient. The concordance correlation coefficient amounted to 0.874 . The obtained data was entered into the decision-making matrix, replacing qualitative assessments by quantitative, and evaluated by scores (Fig. 3).

Several multicriteria methods of option analysis (comparison) are described in the literature (Yazdani-Chamzini et al. 2013b). One multicriteria method is not enough for a more complex tasks. Methods were classified, combined and sequentially applied. The MCDM1 multipurpose complex of methods was used by the authors (Us- tinovichius et al. 2007). This complex consists of TOPSIS, SAW, COPRAS multipurpose methods that are described below.

Preference ranking of alternatives by the COmplex PRoportional ASsessment (COPRAS) method (Zavadskas et al. 2004; Kaklauskas et al. 2005). This method assumes direct and proportional dependence of significance and priority of investigated alternatives on a system of attributes. The system of attributes is determined and experts calculate their values and initial weights. Taking into consideration their goals and existing capabilities, stakeholders (customers, consumers and etc.) can check and correct all the information. Therefore, the results of the alternative assessment provide a detailed outline of the original data of experts and stakeholders.

This method determines the priority of the projects using the formula

$$
Q_{i}=S_{+i}+\frac{S_{-\min } \cdot \sum_{i=1}^{m} S_{-i}}{S_{-i} \cdot \sum_{i=1}^{m} \frac{S_{-\min }}{S_{-i}}}, \quad i=\overline{1, m}
$$

where the significance of the compared alternatives is determined by describing their positive ("pluses" of the project) $S_{+I}$ and negative ("minuses" of the project) $S_{-i}$. The bigger the $Q_{i}$, the better is project efficiency (priority).

Determining preferences of the alternatives based on similarity to an ideal solution method (TOPSIS). Hwang and Yoon (Hwang, Yoon 1981) developed a technique based on the idea that the optimal alternative is most similar to an ideal solution, being at the longest distance from the ideally worst solution. This method is known as Technique for Order Preference by Similarity to Ideal Solution.

A relative distance of any $i^{\text {th }}$ alternative from an ideal one is obtained as:

$$
K_{i}=\frac{L_{i}^{-}}{L_{i}^{+}+L_{i}^{-}}, \quad i=\overline{1, m}, \quad \text { where } K_{i}[0,1],
$$

where: $L_{i}^{+}$is a distance between the compared $i^{\text {th }}$ alternative and the ideal one; $L_{i}^{-}-$a distance between the compared $i^{\text {th }}$ alternative and the negatively ideal option.

The closer to one is the $K_{i}$ value, the closer is the $i^{\text {th }}$ alternative to $a^{+}$, i.e. the optimal alternative is the one that has the highest value of the $K_{i}$.

Determining the efficiency of alternatives by Simple Additive Weighting method (SAW). SAW is well known, simple and widely used. The 


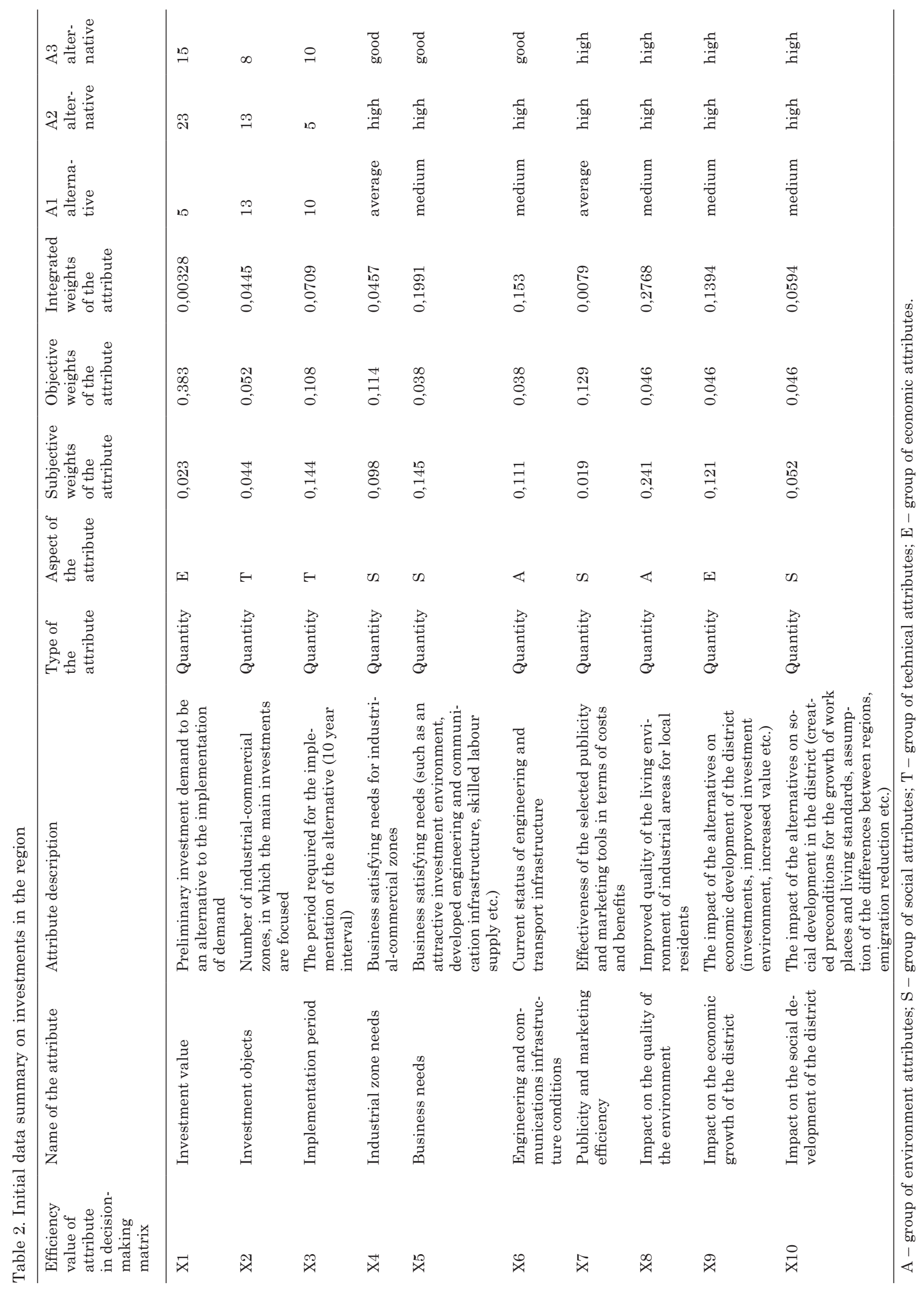




\begin{tabular}{|c|c|c|c|c|c|c|c|c|c|c|c|c|c|c|c|c|c|c|}
\hline 4 & A & B & c & D & E & $\mathrm{F}$ & G & $H$ & 1 & 1 & $\mathrm{~K}$ & $L$ & $M$ & $\mathrm{~N}$ & 0 & $P$ & a & $R$ \\
\hline 1 & Home & & Dec & sion & latrix & COPRAS & TOPSIS & & igation & & & Objecti & VeightCak & & SAW & & Demo & \\
\hline$\frac{2}{3}$ & $\begin{array}{l}\operatorname{Row}(3) \\
\operatorname{Cot}(10)\end{array}$ & $\min$ & min & $\min$ & $\max$ & $\max$ & $\max$ & $\max$ & $\max$ & $\max$ & $\max$ & & & & & & & \\
\hline 4 & & $x_{1}$ & $\times 2$ & $x_{3}$ & $x 4$ & X5 & $x_{6}$ & $x 7$ & $X B$ & $x 9$ & $\mathrm{x} 10$ & & & & & & & \\
\hline 5 & A1 & 5 & 13 & 10 & 2 & 3 & 3 & 2 & 3 & 3 & 3 & & & & & & & \\
\hline 6 & $A 2$ & 23 & 13 & 5 & 5 & 5 & 5 & 5 & 5 & 5 & 5 & & & & & & & \\
\hline 7 & $\mathrm{A3}$ & 15 & 3 & 10 & 4 & 4 & 4 & 5 & 5 & 5 & 5 & & & & & & & \\
\hline 8 & & & & & & & & & & & & & & & & & & \\
\hline
\end{tabular}

Fig. 3. Introduced decision-making matrix using MCDM1 program

method was summarized by MacCrimmon (MacCrimmon 1968).

Determining the efficiency of the alternative, the respective terms in a normalized matrix are multiplied by weights and summed up. The sum of the products of the optimal alternative will be the maximum:

$$
A=\left\{A_{i} \mid \max _{i} \sum_{j=1}^{n} \overline{q_{j} x_{i j}} / \sum_{j=1}^{n} \overline{q_{j}}\right\},
$$

where: $\overline{x_{i j}}-$ normalized alternative vs. attribute matrix.

Alternatives are described using the efficiency criteria and are assessed using the MCDM1 program. The program uses COPRAS, TOPSIS, SAW multicriteria quantitative assessment methods. The result indicates the best strategic development direction that is expected to maximize the investment in the region and ensure its sustainable development. In order to integrate the verbal indicators with the quantitative methods applied in the research, a five point scale was used. The verbal indicators were translated to points according to the following rule: poor -1 ; average -2 ; medium -3 ; good -4 ; high -5 . The decision matrix is shown in Figure 3 and the results are presented in Table 3.

It was found that the best alternative was $A 2-$ "maximum investments". A3 alternative "efficient investments" took the second place and the alternative $A 1$ "minimum investments" was ranked third. The first place was given to the investments

Table 3. The results

\begin{tabular}{|c|c|c|c|c|c|c|}
\hline \multirow{2}{*}{ 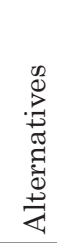 } & \multicolumn{6}{|c|}{ Methods and their ranges } \\
\hline & 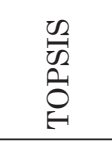 & 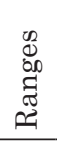 & $\begin{array}{l}\frac{2}{4} \\
\frac{1}{2} \\
0 \\
0\end{array}$ & 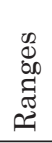 & $\sum_{\text {崖 }}$ & 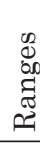 \\
\hline$A 1$ & 0,0183 & 3 & 0,241 & 3 & 0,584 & 3 \\
\hline$A 2$ & 0,9092 & 1 & 0,400 & 1 & 0,981 & 1 \\
\hline$A 3$ & 0,6787 & 2 & 0,359 & 2 & 0,883 & 2 \\
\hline
\end{tabular}

alternative, which is defined as follows: the priority of the District of Vilnius is given to the development of industrial-commercial zones and maximal investments assigned in a very short period of time. Additionally, a publicity program of the District of Vilnius for investments and industry was also carried out.

\section{CONCLUSIONS}

1. It was proven that investments are necessary for the sustainable development of a region. The theoretical model of strategic investments was introduced to identify the opportunities to increase the investment attractiveness. The model has four parts: macro-economic analysis, analysis of the investment climate, analysis of the investment strategy and decision-making. This system aims to determine the development direction for a region, maximize strengths and opportunities of the region, and attract investments purposefully to the defined business branches and/or areas.

2. The proposed framework of investment alternatives reflects the lack of connection between the practical investment stimulation and sustainable development attributes. The model mentioned above was used as an example for a certain region. Three alternatives were set for industrial-commercial zone development: $A 1$ - "minimum investments", $A 2$ - "maximum investments, and $A 3$ - "efficient investments". The attributes of the alternatives, their types, aspects directions and weights were identified.

3. One multicriteria method is not enough for solving real-life tasks characterized by high complexity. The MCMD1 complex of multicriteria methods, consisting of TOPSIS, SAW, COPRAS methods, was use by the authors. In order to determine the best alternative, all three multicriteria methods (TOPSIS, SAW and COPRAS) were used to solve the task. It was determined that the priority of Vilnius District Municipality should be the development of industrialcommercial zones and maximal investments in a very short period of time. 


\section{REFERENCES}

Brown, M. A. 2012. Construction management: the management of the development, conservation and improvement of the built environment, Organization, Technology \& Management in Construction: An international Journal 4(2): 457-460. http://dx.doi. org/10.5592/otmcj.2012.2.1

Cha, H. S.; Kim, Ch. K. 2011. Quantitative approach for project performance measurement on building construction in South Korea, KSCE Journal of Civil Engineering 15(8): 1319-1328. http://dx.doi.org/10.1007/ s12205-011-1323-5

Cook, W. D.; Kress, M. 1994. A multiple-criteria composite index model for quantitative and qualitative data, European Journal of Operational Research 78(3): 367-379. http://dx.doi.org/10.1016/03772217(94)90046-9

Dahl, A. L. 2012. Achievements and gaps in indicators for sustainability, Ecological Indicators 17: 14-19. http://dx.doi.org/10.1016/j.ecolind.2011.04.032

Falla, D. F. T.; Olarte, L. C. B.; Bejarano, J. M. G. 2009. Foreign direct investment in Latin America and its effects over development 1990-2006, Journal of Economics and Management 58(3): 263-280. http:// dx.doi.org/10.1111/1467-8489.12036

Fouladgar, M. M.; Yazdani-Chamzini, A.; Zavadskas, E. K.; Yakhchali, S. H.; Ghasempourabadi, M. H. 2012. Project portfolio selection using Fuzzy AHP and Vikor techniques, Transformations in Business \& Economics 11(1): 213-231.

Galinienè, B., Mašalaitytė, L. 2007. Verslo vertinimo kokybei turinys ittakos finansinès analizès aspektai [Business valuation impact on the quality of the content aspects of financial analysis], Ekonomika 77: 7-23.

Ghosh, S; Amaya, L.; Skibniewski, M. J. 2012. Identifying areas of knowledge governance for successful projects, Journal of Civil Engineering and Management 18(4): 495-504. http://dx.doi.org/10.3846/13923 730.2012 .700642

Ginevičius, R.; Bruzgè, Š. 2008. Išlaidu ir naudos analizès taikymo galimybès valstybès priimamoms reguliavimo priemonèms vertinti [Possibilities of using the cost-benefit analysis for the evaluation of government regulation measures], Verslas: teorija ir praktika 9(3): 180-189. http://dx.doi. org/10.3846/1648-0627.2008.9.180-189

Ginevičius, R.; Podvezko, V. 2009. Evaluating the changes in economic and social development of Lithuanian counties by multiple criteria methods, Technological and Economic Development of Economy 15(3): 418436. http://dx.doi.org/10.3846/1392-8619.2009.15.418436

Ginevičius, R.; Šimelytè, A. 2012. The effect of regulatory incentives on bilateral foreign direct investment, in Proceedings of the $7^{\text {th }}$ International Scientific Conference Business and Management, 10-11 May, 2012, 66-74.

Hwang, C. L.; Yoon, K. 1981. Multiple attribute decision making - methods and applications. A state of the art survey. Springer Verlag, Berlin, Heidelberg, New York.
Yazdani-Chamzini, A.; Razani, M.; Yakhchali, S. H.; Zavadskas, E. K.; Turskis, Z. 2013a. Developing a fuzzy model based on subtractive clustering for road header performance prediction, Automation in Construction 35: 111-120. http://dx.doi.org/10.1016/j.autcon.2013.04.001

Yazdani-Chamzini, A.; Fouladgar, M. M.; Zavadskas, E. K.; Haji Moini, S. H. 2013b. Selecting the optimal renewable energy using multi criteria decision making, Journal of Business Economics and Management 14(5): 957-978. http://dx.doi.org/10.3846/16111699.2 013.766257

Jakaitis, J.; Paliulis, N.; Jakaitis, K. 2009. Aspects of the national urban policy management under conditions of integrated planning, Technological and Economic Development of Economy 15(1): 26-38. http:// dx.doi.org/10.3846/1392-8619.2009.15.26-38

Kaklauskas, A.; Zavadskas, E. K.; Raslanas, S. 2005. Multivariant design and multiple criteria analysis of building refurbishments, Energy and Buildings 37(4): 361-372. http://dx.doi.org/10.1016/j.enbuild.2004.07.005

Keršytè, A. 2010. Strateginių investicinių projektų vertinimas: daugiakriterinis požiūris [Appraisal of strategic investment decisions: multi-attribute approach], Ekonomika ir vadyba 15: 947-953.

Liang, G. S.; Wang, M. J. J. 1994. Personnel selection using fuzzy MCDM algorithm, European Journal of Operational Research 78: 22-33. http://dx.doi. org/10.1016/0377-2217(94)90119-8

Lim, S. H. 2008. How investment promotion affects attracting foreign direct investment: analytical argument and empirical analysis, International Business Review 17(1): 39-53. http://dx.doi.org/10.1016/j.ibusrev.2007.09.001

MacCrimmon, K. R. 1968. Decision marking among multiple-attribute alternatives: a survey and consolidated approach, RAND Memorandum, RM-4823-ARPA.

Marques, G.; Gourc, D.; Lauras, M. 2011. Multi-criteria performance analysis for decision making in project management, International Journal of Project Management 29(8): 1057-1069. http://dx.doi.org/10.1016/j. ijproman.2010.10.002

Meng, X. 2012. The effect of relationship management on project performance in construction, International Journal of Project Management 30(2): 188-198. http://dx.doi.org/10.1016/j.ijproman.2011.04.002

Mori, K.; Christodoulou, A. 2012. Review of sustainability indices and indicators: towards a new city sustainability index (CSI), Environmental Impact Assessment Review 32(1): 94-106. http://dx.doi. org/10.1016/j.eiar.2011.06.001

Nausėda, A.; Tamošiūnas, T. 2009. Lietuvos regioninès politikos kaitos tendencijos Europos Sajungos kontekste [Changes of Lithuanian regional policy in the European Union context], Ekonomika ir vadyba: aktualijos ir perspektyvos 1(14): 177-186.

Negahban, S. S.; Baecher, G. B.; Skibniewski, M. J. 2012. A decision-making model for adoption of enterprise resource planning tools by small-to-medium size construction organizations, Journal of Civil Engineering and Management 8(2): 253-264. http:// dx.doi.org/10.3846/13923730.2012.666503 
Niccolucci, V.; Tiezzi, E.; Pulselli, F. M.; Capineri, C. 2012. Biocapacity us ecological footprint of world regions: a geopolitical interpretation, Ecological Indicators 16: 23-30. http://dx.doi.org/10.1016/j.ecolind.2011.09.002

Paliokaitè, A.; Gaušas, S.; De Reuwe, G.; Stravinskas, J. 2007. Pramoniniu parku plètros galimybiu ivertinimo studija (Galutine ataskaita) [Feasibility study on the development of an industrial park (Final Report)]. Viešosios politikos ir vadybos institutas, Vilnius.

Ruane, M.C. 2008. Attracting foreign direct investments: challenges and opportunities for smaller host economies, Journal of International Business Research 7(2): 65-74. http://dx.doi.org/10.1023/A:1012648521593

Ruplienè, D.; Montvilaitė, K.; Grigaliūnienè, Ž. 2008. Tiesiogines užsienio investicijas lemiantys veiksniai [Determinants of foreign direct investments], Ekonomika ir vadyba: aktualijos ir perspektyvos 3(12): 271-280.

Ruplienè, D; Garšvienè, L. 2008. Tiesioginių užsienio investicijų itaka šalies ekonominiam augimui [Impact of foreign direct investments on national economic growth], Ekonomika ir vadyba: aktualijos perspektyvos 3(12): 262-270.

Rutkauskas, A. V.; Miečinskienè, A.; Stasytytè, V. 2008. Investment decisions modelling along sustainable development concept on financial markets, Technological and Economic Development of Economy 14(3): 417-427. http://dx.doi.org/10.3846/13928619.2008.14.417-427

Saaty, T. L. 1977. A scaling method for priorities in hierarchical structures, Journal of Mathematical Psychology 15(3): 234-281. http://dx.doi.org/10.1016/00222496(77)90033-5

Sakalauskas, L.; Zavadskas, E. K. 2009. Optimization and intelligent decisions, Technological and Economic Development of Economy 15(2): 189-196. http:// dx.doi.org/10.3846/1392-8619.2009.15.189-196

Singh, A. 2005. FDI, Globalization and economic development: towards reforming national and international rules, ESRC Centre of Business Research, University of Cambridge Working papers No. 304, 30.

Skibniewski, M. J.; Zavadskas, E. K. 2013. Technology development in construction: a continuum from distant past into the future, Journal of Civil Engineering and Management 19(1): 136-147. http://dx.doi.or $\mathrm{g} / 10.3846 / 13923730.2012 .756060$
Triantaphyllou, E. 2000. Multi-criteria decision making methods: a comparative study. Dordrecht: Kluwer Academic Publishers.

Ustinovichius, L. 2004. Determination of efficiency of investments in construction, International Journal of Strategic Property Management 8(1): 25-44. http:// dx.doi.org/10.1080/1648715X.2004.9637505

Ustinovichius, L.; Barvidas A.; Vishnevskaja, A.; Ashikhmin, I. V. 2011. Multicriteria verbal analysis of territory planning system's models from legislative perspective, Journal of Civil Engineering and Management 17(1): 16-26. http://dx.doi.org/10.3846/1392 3730.2011 .554173

Ustinovichius, L.; Zavadskas, E. K.; Podvezko, V. 2007. Application of a quantitative multiple criteria decision making (MCDM-1) approach to the analysis of investments in construction, Control and Cybernetics 36(1): 256-268. http://dx.doi.org/10.3846/13928619.2009.15.326-340

Ustinovičius, L.; Zavadskas, E. K. 2004. Statybos investiciju efektyvumo sistemotechninis ivertinimas [Assessment of investment profitability in construction from technological perspectives]. Vilnius: Technika.

Zavadskas, E. K.; Vilutiene, T., Turskis, Z.; Šaparauskas, J. 2014. Multi-criteria analysis of projects' performance in construction, Archives of Civil and $\mathrm{Me}$ chanical Engineering 14: 114-121. http://dx.doi. org/10.1016/j.acme.2013.07.006

Zavadskas, E. K.; Turskis, Z. 2011. Multiple criteria decision making (MCDM) methods in economics: an overview, Technological and Economic Development of Economy 17(2): 397-427. http://dx.doi.org/10.3846 /20294913.2011.593291

Zavadskas, E. K.; Kaklauskas, A.; Banaitis, A.; Kvederyte, N. 2004. Housing credit access model: the case for Lithuania, European Journal of Operational Research 155(2), 335-352. http://dx.doi.org/10.3846/202 94913.2011 .593291

Zolfani, S. H.; Chen, I-Sh.; Rezaeiniya, N.; Tamošaitiene, J. 2012. A hybrid MCDM model encompassing AHP and COPRAS-G methods for selecting company supplier in Iran, Technological and Economic Development of Economy 18(3): 529-543. http://dx.doi.org/10 .3846/20294913.2012.709472 